\title{
WINTER 2020
}

\section{The}

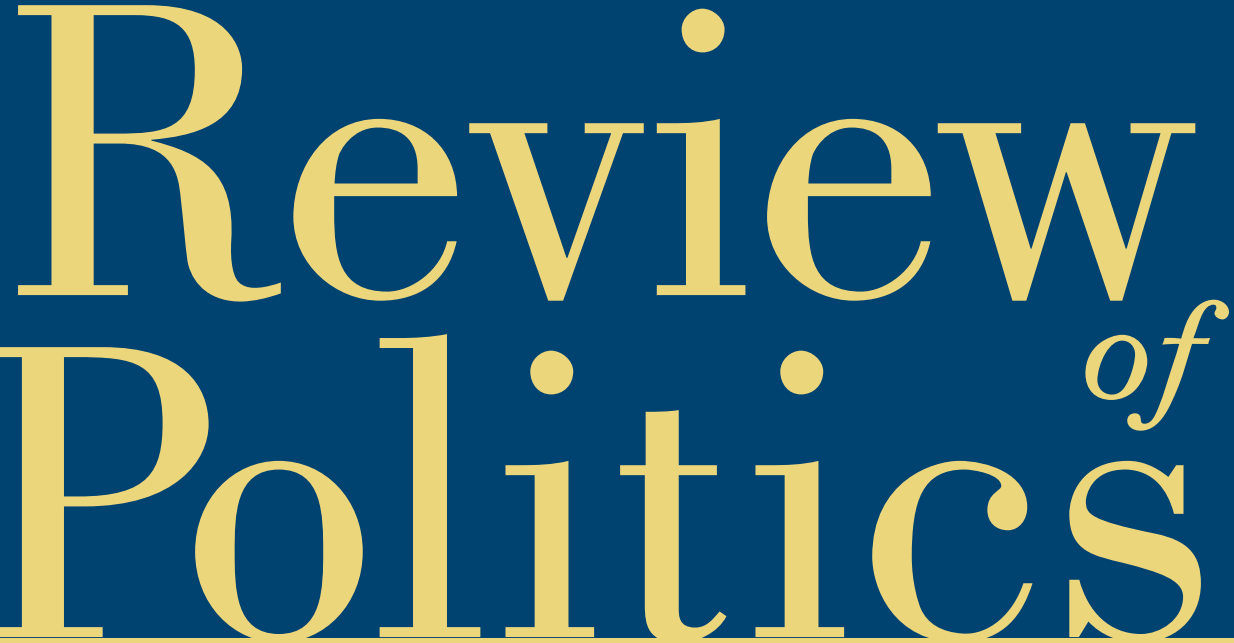

ARTICLES

George Duke, "Aristotle and Natural Law"

Elizabeth Frazer, "Mary Wollstonecraft's Political Political Theory"

Alec Arellano, "Tocqueville on Intellectual Independence, Doubt, and Democratic Citizenship"

Simon Townsend, "Nietzsche on the Rise of Strong Political States and Their Cultivation of Higher Individuals"

Nathan J. Pinkoski, "Alasdair MacIntyre and Leo Strauss on the Activity of Philosophy"

SYMPOSIUM

PaulT. Wilford, GeoffreyM. Vaughan, Paul Franco, Ioannis D. Evirgenis, and Bryan Garsten on Devin Stauffer's Hobbes's Kingdom of Light, with a response by Devin Stauffer

Review Essay: Kevin Bruyneel, "On Settler Colonialism" 


\title{
THE REVIEW OF POLITICS
}

\author{
Editor
}

RUTH ABBEY

Book Review Editor

SUSAN D. COLLINS

\section{Editorial Coordinator \\ KELLI BROWN}

\section{Editorial Board}

\author{
Shlomo Avineri \\ Hebrew University of Jerusalem \\ Simone Chambers \\ University of California, Irvine \\ Fred Dallmayr \\ University of Notre Dame \\ Elizabeth Frazer \\ University of Oxford \\ Michael A. Gillespie \\ Duke University \\ Leslie Goldstein \\ University of Delaware \\ Russell Hittinger \\ University of Tulsa \\ Ramin Jahanbegloo \\ York University
}

\author{
A. James McAdams \\ University of Notre Dame \\ Daniel Philpott \\ University of Notre Dame \\ Arlene Saxonhouse \\ University of Michigan \\ William E. Scheuerman \\ Indiana University, Bloomington \\ John T. Scott \\ University of California, Davis \\ Steven B. Smith \\ Yale University \\ Peter Steinberger \\ Reed College \\ Vickie Sullivan \\ Tufts University
}

\section{Copyeditor: LES HARRIS}

Editorial Interns: Mary Shiraef and Robert Wyllie

\section{Former Editors}

\author{
Waldemar Gurian \\ M.A. Fitzsimons \\ Thomas Stritch \\ Frederick J. Crosson
}

Donald P. Kommers

Walter Nicgorski

Catherine Zuckert

\begin{abstract}
The Review of Politics publishes primarily philosophical and historical studies of politics, especially those in political theory and American political thought. The journal also includes thoughtful scholarly reflections on all aspects of politics-laws, and institutions, international relations, comparative politics - as well as literary reflections on politics or political interpretations of literature.
\end{abstract}




\section{TABLE OF CONTENTS WINTER 2020}

Vol. 82

WINTER 2020

No. 1

George Duke

Aristotle and Natural Law ................. 1

Elizabeth Frazer

Mary Wollstonecraft's Political Political Theory . . . . . . . . . 25

Alec Arellano

Tocqueville on Intellectual Independence, Doubt, and

Democratic Citizenship . . . . . . . . . . . . . . . . . . . 49

Simon Townsend

Nietzsche on the Rise of Strong Political States and Their

Cultivation of Higher Individuals . . . . . . . . . . 73

Nathan J. Pinkoski

Alasdair MacIntyre and Leo Strauss on the Activity of

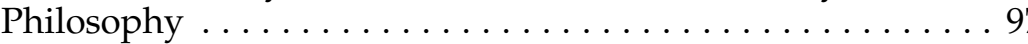

\section{Symposium:}

Paul T. Wilford, Geoffrey M. Vaughan, Paul Franco, Ioannis D. Evirgenis, and Bryan Garsten on Devin Stauffer's Hobbes's Kingdom of Light: A Study of the

Foundations of Modern Political Philosophy, with a response by Devin

Stauffer................................... 123

Review Essay:

Kevin Bruyneel

On Settler Colonialism

Reviews:

Matthew R. Petrusek

Review of Jean Bethke Elshtain's Augustine and the Limits of Politics and Debra Erickson and Michael Le Chevallier's (eds.) Jean Bethke Elshtain: Politics, Ethics, and Society. . . . . . . . . . . . . . 159

Samuel Bagg

Review of Jeff Jackson's Equality beyond Debate: John Dewey's

Pragmatic Idea of Democracy. . . . . . . . . . . . . . . . . . . . . . . . . . . . . 164

Kimberley Burns

Review of Nelson Lund's Rousseau's Rejuvenation of

Political Philosophy: A New Introduction. .

Richard Dagger

Review of Milena Tripković's Punishment and Citizenship:

A Theory of Criminal Disenfranchisement 
Robert Devigne

Review of Chris Barker's Educating Liberty: Democracy and Aristocracy in J. S. Mill's Political Thought. . . . . . . . . . . . . . . . 173

Richard W. Garnett

Review of Ellis M. West's The Free Exercise of Religion in

America: Its Original Constitutional Meaning . . . . . . . . . . . . . 175

Allison Murphy

Review of John von Heyking's Comprehensive Judgment and

Absolute Selflessness: Winston Churchill on Politics as Friendship . . . . . 178

Madadh Richey

Review of Aaron Tugendhaft's Baal and the Politics of Poetry . . . . . . 181

Joel Alden Schlosser

Review of John Lombardini's The Politics of

Socratic Humor. . . . . . . . . . . . . . . . . . . . . . . . . . . . . . . . . . . 184

James P. Sterba

Review of Michael Goodhart's Injustice: Political Theory

for the Real World . . . . . . . . . . . . . . . . . . . . . . . . . . . . . . . . . 187

Milena Tripkovic

Review of Richard Dagger's Playing Fair: Political Obligation

and the Problems of Punishment . . . . . . . . . . . . . . . . . . . . 189

Emily Zackin

Review of Leslie F. Goldstein's The U.S. Supreme Court and

Racial Minorities: Two Centuries of Judicial Review on Trial. . . . . . . . . . .192

\section{CORRIGENDA:}

Joan Cocks

Demetra Kasimis: The Perpetual Immigrant and the Limits of

Athenian Democracy-CORRIGENDUM . . . . . . . . . . . . . . . . . . 195

Michael E. Zimmerman

Ronald Beiner: Dangerous Minds: Nietzsche, Heidegger, and the Return of the Far Right-CORRIGENDUM 
Subscription Information: The Review of Politics (ISSN 0034-6705) is published quarterly in February, May, August and November by Cambridge University Press, One Liberty Plaza, 20th Floor, New York, NY 10006, USA/University Printing House, Shaftesbury Road, Cambridge CB2 8BS, UK for the University of Notre Dame. Annual subscription rates for Volume 82 (2020): Institutional subscription rates, print and online: US $\$ 229.00$ in the USA, Canada, and Mexico; UK $£ 135.00$ + VAT elsewhere. Institutional subscription rates, online only: US $\$ 189.00$ in the USA, Canada, and Mexico; UK $£ 116.00$ + VAT elsewhere. Institutional subscription rates, print only: US \$218.00 in the USA, Canada, and Mexico; UK $£ 132.00+$ VAT elsewhere. Individual subscription rates, print only: US $\$ 54.00$ in the USA, Canada, and Mexico; UK $£ 31.00$ + VAT elsewhere. Single part rates: US $\$ 63.00$ in the USA, Canada, and Mexico; UK £38.00. Correspondence concerning subscriptions should be sent to: Cambridge University Press, One Liberty Plaza, 20th Floor, New York, NY 10006, USA for customers in the USA, Canada, or Mexico. Customers elsewhere should contact: Cambridge University Press, University Printing House, Shaftesbury Road, Cambridge CB2 8BS, UK.

Editorial Office: All correspondence concerning submissions and manuscripts under review should be sent to The Review of Politics, University of Notre Dame, 2005 Jenkins Nanovic Halls, Notre Dame, IN 46556-7000. Phone: 574-631-6623. Email: ROP.Editor.1@nd.edu. Website: reviewofpolitics.nd.edu

Abstracting and Indexing Information: Articles in The Review of Politics are indexed in the International Index to Periodicals and the Catholic Periodicals and Literature Index; abstracted in the International Political Science Abstracts; and abstracted and indexed in ABC POL. SCI., Historical Abstracts, Social Science Index (also available in the electronic versions), Book Review Index, and International Bibliography of the Social Sciences.

Copyright (C) 2020 University of Notre Dame. All rights reserved. No part of this publication may be reproduced, in any form or by any means, electronic, photocopy, or otherwise, without permission in writing from Cambridge University Press, Rights and Permissions Manager, One Liberty Plaza, 20th Floor, New York, NY 10006, USA. For further information see http://us.cambridge/org/information/rights/

Periodicals postage paid in New York, NY and additional mailing offices. Postmaster: Send address changes to The Review of Politics, Cambridge University Press, One Liberty Plaza, 20th Floor, New York, NY 10006, USA.

Photocopying information for users in the U.S.A.: the Item-Fee Code for the publication (0034-6705/18 \$9.00+.10) indicates that copying for internal or personal use beyond that permitted by Sec. 107 or 108 of the U.S. Copyright Law is authorized for users duly registered with the Copyright Clearance Center (CCC) provided that the appropriate remittance of $\$ 9.00$ per article is paid directly to CCC, 222 Rosewood Drive, Danvers, MA 01923. Specific written permission must be obtained for all other copying. 